\title{
Seed bank raises hope of Iraqi crop comeback
}

Tom Clarke, London

Agricultural scientists in Syria are sitting on a 'black box' of seed samples that could help plant research to get back on its feet in Iraq - if the security situation there improves.

The collection of more than 200 seed samples, removed from Iraq in 1996 and stored at the International Center for Agricultural Research in the Dry Areas (ICARDA) in Aleppo, should ease the restoration of agricultural research in Iraq, researchers say.

But a seed bank will be worthless without a functioning agricultural sector to use it. At a press conference in Washington DC on 10 July, Dan Amstutz, the former agribusiness executive appointed by the US Department of Agriculture to reconstruct Iraqi farming, admitted that the deteriorating security situation had forced that effort into retreat. "We viewed getting out and talking to farmers as an enormously important part of our function," he said, "and that's more difficult now."

In the short term, restoring Iraq's agriculture hinges on ensuring that farmers have enough seed to plant and the means to harvest it. But the genetic diversity held in seed banks is crucial to long-term farm productivity, experts say. Seeds that confer resistance to pests, diseases or drought but are also adapted to the local environment are essential for sustainable production.

None of the 1,400 crop varieties stored in Iraq's Abu Gharib national gene bank, near Baghdad, is thought to have survived the aftermath of this year's invasion by the United States and Britain, says William Erskine, ICARDA's research director.

But seven years ago, scientists at $\mathrm{Abu}$ Gharib, alarmed by deteriorating conditions in their own country, sent samples to ICARDA

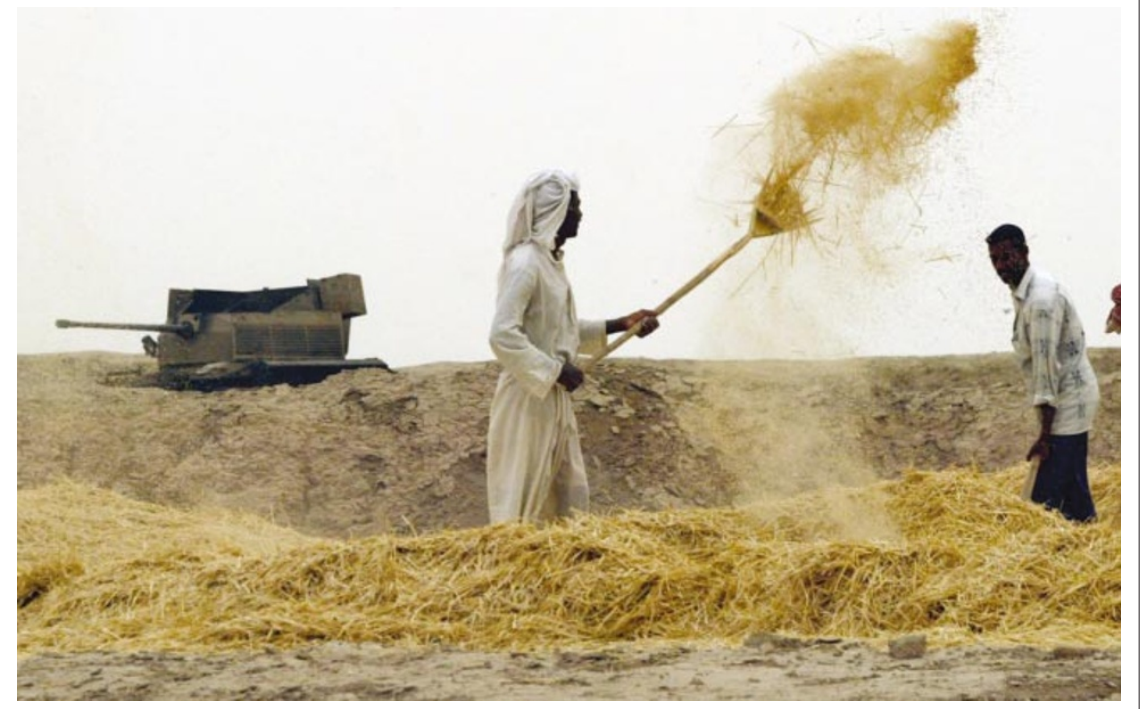

Despite the ravages of sanctions and war, hopes remain that Iraq's agricultural prowess can be revived.

for safe-keeping. "Someone at Abu Gharib showed great foresight," says Erskine. The collection contains more than 200 of the most valuable varieties of 28 different crops.

Plant scientists hope that other varieties can also be saved. Iraq occupies an area that was probably the first in the world to refine the agriculture of such crops as wheat and barley — making local strains particularly interesting to plant scientists globally. This makes it more likely that the remaining 1,200 varieties in Abu Gharib's original collection can eventually be located. "Seeds from the region were well collected in the past," says Mike Ambrose, a crop geneticist at the John Innes Centre in Norwich, UK. "I'd hope that a lot of them can be repatriated," he says.
Researchers are also keen to salvage Iraq's own crop-science prowess, which remained considerable despite its erosion during the time of United Nations sanctions. "We need to get back quickly to prevent a diaspora of scientific expertise," says Erskine.

In May, the US Agency for International Development began inviting applications from US companies or non-profit organizations to begin rebuilding Iraq's agricultural infrastructure, and for partnerships between US and Iraqi universities to bolster research. No contract has yet been awarded - the largest restoration job to date has been an $\$ 800,000$ US project to restore basic amenities at the agriculture ministry's looted headquarters in Baghdad.

\section{Ants join online colony to boost conservation efforts}

\section{Rex Dalton, San Francisco}

An Internet-based system of ant images is expected to help ecologists study and preserve global biodiversity.

The website, www.antweb.org, provides researchers with three-dimensional images of thousands of ant species, along with all of the information held in traditional catalogues of species.

"This sets new standards for doing taxonomy online," says Brian Fisher, an entomologist at the California Academy of Sciences in San Francisco, who led the $\$ 30,000$ project to set up the system.

AntWeb already holds images of many of the world's 10,000 species, including those from California (270 species) and Madagascar (210 species), where more than

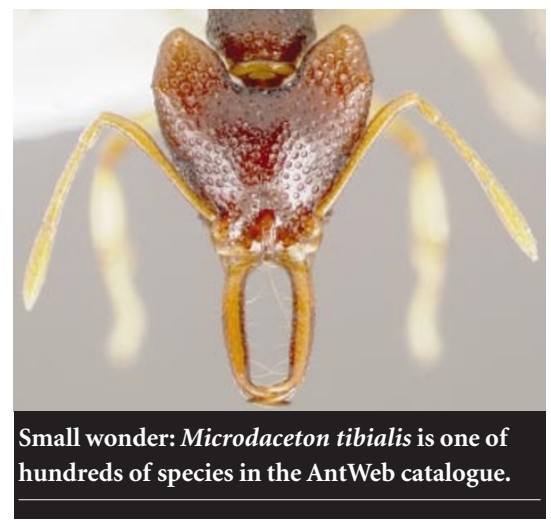

1,000 species are under threat from deforestation. Six hundred species, mainly from Florida, will be added to the website by the end of the year. The eventual goal is to include all of the world's ants.

Ants are important in many ecosystems, and AntWeb is intended to help conservation biologists by providing quick access to information on every ant they come across.

The Nature Conservancy, for example, plans to use AntWeb to help its ecologists manage the Lassen Foothills, an ecologically sensitive region of about $\mathbf{9 0 0 , 0 0 0 ~ h e c t a r e s ~ i n ~ C a l i f o r n i a . ~ " T h e ~}$ evaluation of our conservation efforts is a great challenge," says Mark Reynolds, a Nature Conservancy ecologist based in San Francisco. "AntWeb gives us the ability to know what is happening at the invertebrate level." 